\title{
Sporadic Cases and an Outbreak of Leptospirosis Probably Associated with Recreational Activities in Rivers in the Northern Part of Okinawa Main Island
}

\author{
Masaji NAKAMURA ${ }^{1)}$, Katsuya TAIRA ${ }^{1)}$, Kiyomasa ITOKAZU ${ }^{1)}$, Jun KUDAKA ${ }^{1)}$, Ryuji ASATO ${ }^{1)}$, Tomo’o KISE ${ }^{2)}$ and \\ Nobuo KOIZUMI ${ }^{3)}$ \\ ${ }^{1)}$ Okinawa Prefectural Institute of Health and Environment, 2085 Ozato, Okinawa 901-1202, 2) Department of Pediatrics, Okinawa \\ Prefectural Hokubu Hospital, 2-12-3 Onaka, Nago 905-8512 and ${ }^{3)}$ Department of Bacteriology, National Institute of Infectious \\ Diseases, 1-23-1 Toyama, Shinjuku, Tokyo 162-8640, Japan
}

(Received 1 June 2005/Accepted 16 September 2005)

ABSTRACT. In the summer of 2003, sporadic cases and an outbreak of human leptospirosis probably related to recreation in rivers occurred in the northern part of Okinawa Main Island. Sixteen of 22 suspected cases were definitely diagnosed as leptospirosis by serological test or isolation. The infective leptospiral serovar in 14 cases was presumed to be Hebdomadis. Transmission was thought to occur by exposure to river water that was contaminated by the urine of infected animals. The findings indicate that recreation in rivers in this area is a significant risk factor for infection with leptospires.

KEY WORDS: leptospirosis, recreation, river.

Leptospirosis is the most prevalent zoonosis in the world. The disease in humans is transmitted by direct contact with the urine of infected animals or by exposure to urine-polluted environments [13]. Leptospirosis is endemic in Asia and Central and South America [8], while the disease is rare in Japan, except in Okinawa Prefecture. Okinawa Prefecture is on archipelago located at the southernmost end of Japan. It has a subtropical climate, which is conductive to leptospiral survival in the environment, and the existence of several leptospiral serovars [6] and clusters of human leptospirosis have been reported in Okinawa $[4,9]$. We report here human leptospirosis contracted probably in rivers in the northern part of Okinawa Island in the summer of 2003.

During the period from July to October in 2003, clinical specimens of 22 suspected cases of leptospirosis were obtained at 4 hospitals in Okinawa Prefecture and were sent to the Okinawa Prefectural Institute of Health and Environment for serological test and isolation during the period from August to November in the same year. Serum samples from the patients were tested for the detection of anti-leptospiral antibodies by microscopic agglutination test (MAT). The panel antigens included the following 12 serovars; Australis, Autumnalis, Bataviae, Canicola, Castellonis, Grippotyphosa, Hebdomadis, Icterohaemorrhagiae, Javanica, Pomona, Pyrogenes and Rachmati. The results were interpreted as positive with a four-fold or greater rise in MAT titer between acute-phase and convalescent-phase serum specimens, or a single titer greater than $200[8,13]$. Isolation was performed at the medical institutions by blood culture using commercially available Korthof medium (Denka Seiken, Japan), and culture samples were sent to our institution. The serovars of the isolates were estimated by MAT using 12 anti-leptospiral antisera corresponding to the serovars mentioned above. To deduce the genomospecies of each isolate, we amplified the partial portion of fla $B$ gene of the isolates by PCR with primers as described previously
[7], and the nucleotide sequence was determined with an automated DNA sequencer (ABI 310 sequencer, Applied Biosystems, U.S.A.) using a Big Dye Terminator version 3.1 Cycle Sequencing Kit (Applied Biosystems).

Of the 22 suspected cases, 16 cases were confirmed as leptospirosis by MAT and/or isolation. Table 1 shows the age, sex, and month and place of infection of each patient. The median age of the patients was 19.5 years (range, 5-55 years) and males accounted for 13 cases $(81 \%)$. Most of the patients contracted leptospirosis in the summer season. The incubation period of human leptospirosis is usually 5-14 days with a range of 2-30 days [13]. All patients except Cases 12 and 13 in Table 1 had swum or played in rivers within about one month before the day of onset. In addition, there was no description of opportunity to contract leptospirosis other than recreational activities in rivers in the patient reports from the hospitals. Therefore, in all cases except Cases 12 and 13, the sources of infection were presumed to be recreational activities in rivers. The median age of the patients who were thought to be infected with leptospires in rivers was 16.5 years (range, 5-36 years). Of 14 cases of the fluvial origin, 11 cases were defined as an outbreak (Table 1) because these cases occurred in the same river ( $\mathrm{G}$ River) during the limited period (July to August) and, furthermore, the number of the patients in this occurrence was greater than usual in Okinawa Prefecture. Of the 14 cases with MAT positive, 12 cases showed a rise in antibody titer against serovar Hebdomadis (Table 2). In Cases 4 and 15, the serum samples exhibited MAT titer increase against 3 and 2 serovars, respectively. These results are considered to be cross reaction, but co-infection might be suggested in Case 4, because the rise in antibody titer was confirmed against different serogroups Autumnalis (serovar Autumnalis and Rachmati) and Hebdomadis (serovar Hebdomadis). Leptospires were isolated from 6 patients. The isolates from Cases 1, 7, 10 and 14 were indicated to be 
Table 1. Features of leptospirosis patients in this study

\begin{tabular}{|c|c|c|c|c|c|}
\hline Case & Age & Sex & $\begin{array}{l}\text { Infection } \\
\text { month }\end{array}$ & $\begin{array}{c}\text { Presumed } \\
\text { infection source }\end{array}$ & Definition \\
\hline 1 & 36 & Male & July & $\mathrm{G}$ river & \\
\hline 2 & 18 & Male & July & G river & \\
\hline 3 & 20 & Male & August & $\mathrm{G}$ river & \\
\hline 4 & 12 & Male & August & $\mathrm{G}$ river & \\
\hline 5 & 5 & Male & August & $\mathrm{G}$ river & \\
\hline 6 & 12 & Male & August & G river & Outbreak \\
\hline 7 & 13 & Male & August & G river & \\
\hline 8 & 36 & Female & August & G river & \\
\hline 9 & 10 & Male & August & G river & \\
\hline 10 & 12 & Male & August & G river & \\
\hline 11 & 15 & Male & August & $\mathrm{G}$ river & \\
\hline 12 & 55 & Male & August & Mango field & Sporadic \\
\hline 13 & 26 & Male & August & Unknown & Sporadic \\
\hline 14 & 12 & Male & August & $\mathrm{H}$ river & Sporadic \\
\hline 15 & 9 & Female & September & $S$ river & Sporadic \\
\hline 16 & 21 & Female & October & $O$ river & Sporadic \\
\hline
\end{tabular}

Table 2. Serovars presumed by MATs on patients' sera for anti-leptospiral antibodies (left) and on isolated strains with anti-leptospiral antisera (right)

\begin{tabular}{|c|c|c|}
\hline \multirow[b]{2}{*}{ Case } & \multicolumn{2}{|c|}{ Presumed serovar } \\
\hline & $\begin{array}{l}\text { Exam. of anti-leptospiral } \\
\text { antibody }\end{array}$ & Exam. of isolated strain \\
\hline 1 & Hebdomadis & L.interrogans serovar Hebdomadis \\
\hline 2 & Hebdomadis & \\
\hline 3 & Hebdomadis & \\
\hline 4 & $\begin{array}{c}\text { Autumnalis, Hebdomadis } \\
\text { Rachmati }\end{array}$ & L.interrogans serovar Rachmati \\
\hline 5 & Hebdomadis & \\
\hline 6 & Hebdomadis & \\
\hline 7 & NA & L.interrogans serovar Hebdomadis \\
\hline 8 & Hebdomadis & \\
\hline 9 & Hebdomadis & \\
\hline 10 & Hebdomadis & L.interrogans serovar Hebdomadis \\
\hline 11 & Hebdomadis & \\
\hline 12 & Hebdomadis & \\
\hline 13 & Hebdomadis & \\
\hline 14 & NA & L.interrogans serovar Hebdomadis \\
\hline 15 & Autumnalis, Rachmati & L.interrogans serovar Rachmati \\
\hline 16 & Hebdomadis & \\
\hline
\end{tabular}

NA: not available.

serovar Hebdomadis, whereas the isolates from Cases 4 and 15 were indicated to be serovar Rachmati by MAT using panel antisera. The nucleotide sequences of the partial flaB gene of all the isolates were identical and clustered into L.interrogans in the phylogenetic tree based on the partial leptospiral flaB sequences (data not shown). The symptoms of leptospirosis patients in this study were as follows. Fever $(100 \%)$, headache $(50 \%)$, muscular pain $(50 \%)$, chills (44\%), conjunctivitis $(38 \%)$ and diarrhea $(38 \%)$ were the most common symptoms, and 5 patients developed JarischHerxheimer reaction (31\%). Only 1 patient exhibited severe manifestations (liver and renal failure); the remainder were relatively mild and less severe. In 14 cases, the infective leptospiral serovar was presumed to be Hebdomadis. It is one of the predominant leptospiral serovars found in the northern part of Okinawa Island. Fukumura demonstrated that anti-leptospiral antibodies against serovar Hebdomadis were strongly detected among inhabitants in the same area [6]. Hebdomadis has been frequently isolated from the kidneys of mongoose (personal communication) and more than $50 \%$ of wild boars captured in the northern area had antiHebdomadis antibodies [10]. Serovar Rachmati has also been found in mongoose [6]. Furthermore, approximately $4.1 \%$ of the rodents caught in Okinawa Main Island harbored leptospires, serovars Javanica, Hebdomadis and Castellonis, in their kidneys [10]. These findings strongly suggest that various wild animals serve as reservoirs for several leptospiral serovars in the island's northern part and contaminate soil and water.

Outbreaks of leptospirosis related to flooding and heavy 
rainfall have been reported in Asia and South America [1, 5, 11]. Occurrences of leptospirosis in the summer season in Okinawa may also be associated with heavy rainfall caused by typhoons, which flush pathogenic leptospires in soil into rivers. Many school children were affected by this outbreak, because it occurred during summer vacation (late July - August). The prefectural authority disseminated information on the outbreak to medical institutions, and public health center provided brochures with advice on leptospirosis and its prevention to schools and the general public. In recent years, with the popularity of "ecotourism", the number of people who participate in sports and recreational activities in natural settings which are potentially contaminated with pathogenic leptospires has increased. The $G$ river where 11 people were infected with leptospires has recently drawn attention as a recreational spot, which is one of the reasons why many people were affected in $\mathrm{G}$ river. Cases of leptospirosis associated with adventure sports in rivers and lakes have been reported [2, 3, 12]. Outdoor activities, including river recreation, give participants valuable experience and a respectful appreciation of nature. However, it is also important to make them aware that infectious agents such as pathogenic leptospires may exist in the rivers of Okinawa Island and recreation in rivers has the possibility of contracting leptospirosis.

\section{REFERENCES}

1. Bharadwj, R., Bal, A.M., Joshi, S.A., Kagal, A., Pol, S.S.,
Garad, G., Arjunwadkar, V. and Katti, R. 2002. Jpn. J. Infect. Dis. 55: 194-196.

2. Boland, M., Sayers, G., Coleman, T., Bergin, C., Sheehan, N., Creamer, E., O'Connell, M., Jones, L. and Zochowski, W. 2004. Epidemiol. Infect. 132: 195-200.

3. Centers for Disease Control and prevention. 1998. MMWR Morb. Mortal. Wkly. Rep. 47: 673-676.

4. Corwin, A., Ryan, A., Bloys, W., Thomas, R., Deniega, B. and Watts, D. 1990. Int. J. Epidemiol. 19: 743-748.

5. Easton, A. 1999. Br. Med. J. 319: 212.

6. Fukumura, K. 1984. Yamaguchi Igaku 33: 269-277 (in Japanease).

7. Kawabata, H., Dancel, L.A., Villanueva, S.Y., Yanagihara, Y., Koizumi, N. and Watanabe H. 2001. Microbiol. Immunol. 45: 491-496.

8. Levett, P.N. 2001. Clin. Microbiol. Rev. 14: 296-326.

9. Nakamura, M., 2001. Antibio. Chemoth. 17: 2154-2159 (in Japanease).

10. Nakamura, M., Taira, K., Ohno, A., Masuzawa, T., Kadosaka, T., Kawabata, H., Koizumi, N. and Fujitta, H. 2004. J. Jpn. Vet. Med. Assoc. 57: 321-325 (in Japanease).

11. Sehgal, S.C., Sugunan, A.P. and Vijayachari, P. 2002. Natl. Med. J. India. 15: 22-23.

12. Sejvar, J., Bancroft, E., Winthrop, K., Bettinger, J., Bajani, M., Bragg, S., Shutt, K., Kaiser, R., Marano, N., Popovic, T., Tappero, J., Ashford, D., Mascola, L., Vugia, D., Perkins, B. and Rosenstein, N. 2003. Emerg. Infect. Dis. 9: 702-707.

13. World Health Organization and International Leptospirosis Society. 2003. Human Leptospirosis: Guidance for diagnosis, surveillance and control, WHO press, Geneva, Switzerland. 